\title{
Growing of Black Locust (Robinia pseudoacacia L.) Candidate Cultivars on Arid Sandy Site
}

\author{
Zsolt KESERÜ $\mathrm{a}^{\mathrm{a}}-$ Attila BOROVICS $^{\mathrm{a}}-$ Tamás ÁBRI $^{\mathrm{a}, \mathrm{b}}-$ Károly RÉDEI $^{\mathrm{b}}-$ \\ Il Hwan LEE ${ }^{\mathrm{c}}-$ Hyemin LIM $^{\mathrm{c}}$
}

\author{
${ }^{a}$ Forest Research Institute, University of Sopron, Sopron, Hungary \\ ${ }^{\mathrm{b}}$ Faculty of Agricultural and Food Sciences and Environmental Management, University of Debrecen, \\ Debrecen, Hungary \\ ${ }^{\mathrm{c}}$ Division of Forest Improvement, National Institute of Forest Science, Suwon, Republic of Korea
}

\begin{abstract}
In the late 1990s, Hungarian Forest Research Institute researchers produced 15 micropropogated black locust (Robinia pseudoacacia L.) clones as part of a program to select clones that could be successfully grown on arid sites. Five of these clones (R.p. 'Vacsi', R.p. 'Szálas', R.p. 'Oszlopos', R.p. 'Homoki' and R.p. 'Bácska') have been categorized as cultivar candidates. The current study presents information concerning the 'Bácska', 'Vacsi' and 'Homoki' candidate cultivars. Based on research results obtained thus far, the three aforementioned candidate cultivars seem the most promising. The cultivars, aged 6-15 years, were tested in a variety comparison trial under arid, sandy soil conditions in the Danube-Tisza Interfluve near the town of Helvécia. Significant differences $(\mathrm{p}<0.05)$ were observed during results evaluation of full inventories and during the comparison of candidate cultivars partly with common black locust and partly with 'Jászkiséri' cultivars. The 15-yearold 'Homoki' outperformed common black locust in diameter and mean tree volume; 'Vacsi' outperformed in stem quality. The 14-year-old 'Bácska' candidate cultivar was compared with the 'Jászkiséri' cultivar and the 'Oszlopos' cultivar candidate. 'Bácska' proved to be significantly better in diameter and mean tree volume than Jászkiséri', but weaker in trunk quality.

The South Korean National Institute of Forest Science has supported this research for several years. The growing technology of the mentioned candidate cultivars are also examined in Korea, taking local ecological conditions into account.
\end{abstract}

\section{Robinia pseudoacacia / micropropagation / selection / black locust growing}

Kivonat - Akácfajtajelöltek termesztése szárazodó homoki termőhelyen. Az 1990-es évek végén az Erdészeti Tudományos Intézet kutatói a szárazodó termőhelyeken is eredményesen termeszthető akácklónok szelektálását célul kitüző program keretében 15 klónt állítottak elö, amelyből öt (R.p.'Vacsi', R.p.'Szálas', R.p.'Oszlopos', R.p.'Homoki' és R.p.'Bácska') fajtajelölti minősítést kapott. Jelen tanulmányban, a fentebb említett fajtajelöltek közül, a 'Bácska', a 'Vacsi' és a 'Homoki' kerülnek bemutatásra. Az eddigi vizsgálati eredmények alapján ez a három fajtajelölt tünik a legígéretesebbnek. A fajtajelölteket a Duna-Tisza közi homokhátságon (Helvécia település közelében), szárazodó, gyenge homoki termőhelyen létesült fajta összehasonlító kísérletben vizsgáltuk 6-15 éves korban. Az állományfelvételek eredményeinek kiértékelése, a fajtajelölteknek részben a közönséges akáccal, részben a 'Jászkiséri' akáccal történő összehasonlítása során szignifikáns különbségeket tapasztaltunk. A 15 éves 'Homoki' átmérő, és átlagfa-térfogat, a 'Vacsi' törzsminőség tekintetében múlta felül a közönséges akácot. A 'Bácska' fajtajelöltet a 'Jászkiséri' fajtával, valamint az 'Oszlopos' fajtajelölttel hasonlítottuk

\footnotetext{
* Corresponding author: keseru.zsolt@uni-sopron.hu; H-4150 PÜSPÖKLADÁNY, Farkassziget 4, Hungary
} 
össze, ahol a 14 éves 'Bácska' átméröben és átlagfa-térfogatban szignifikánsan jobbnak, törzsminőségben viszont gyengébbnek bizonyult a 'Jászkisérinél'.

Ezt a kutatómunkát több éve támogatja a Dél-Koreai Erdészettudományi Intézet, ahol az említett fajtajelöltek termesztési technológiai tulajdonságait szintén vizsgálják az ottani ökológiai feltételek figyelembevétele mellett.

Robinia pseudoacacia / mikroszaporítás / szelekció / akáctermesztés

\section{INTRODUCTION}

Black locust (Robinia pseudoacacia L.), a hard broadleaved tree species, originates from North America. The estimated area of black locust plantations beyond the native range is approx. 3 million ha globally (Schneck 2010). The fast spread of black locust can be expected in two continents in the future: Asia, primarily in the countries of China and South Korea; and Europe, with Hungary, Romania, Poland and some Mediterranean countries (mostly Bulgaria, Italy, France, Turkey) being the most prominent black locust growers (Li et al. 2014, Nicolescu 2020).

Black locust was introduced to Europe more than 400 years ago (Demené - Merzeau 2007). In Hungary, the first records of black locust introduction date back to the 18th century. Since then, black locust area has been steadily increasing (Vadas 1911, Keresztesi 1988). Currently the species covers approx. 24\% of forested area in Hungary (HCSO 2019). Black locust was introduced to South Korea in the $19^{\text {th }}$ century. After the Korean War in the 1960s, it was heavily used in the reforestation of denuded mountains. Recently, black locust is one of the most extensively established exotic tree species in Hungary and South Korea. Its widespread growth can be attributed to its drought tolerance, frequent and abundant seed production, rapid growth, relatively high tree yielding potential, good honey production, excellent vegetative regeneration ability, and low susceptibility to pest and pathogens. Its role in soil protection (erosion and deflation control) is also decisive. Black locust wood is durable, high quality, and is utilized for many purposes (Keresztesi 1988, Lee et a. 2004, Noh et al. 2010, Rédei 2013, Lee et al. 2019, Nicolescu et al. 2020). In addition to its many advantageous properties, its ability to propagate aggressively and its inability to associate due to its high light demand and strong root competition should not be overlooked (Vítková et al. 2015, 2017). Furthermore, common black locust may also possess negative tree characteristics to varying degrees. These include warped and space-curved trunks as well as forking and low industrial wood yields, all of which are disadvantageous for growing (Keresztesi 1988).

Hungarian Forest Research Institute (FRI) staff have been improving black locust growing technology for decades, including the creation and introduction of selected black locust cultivars, the primary goal of which is to improve stem quality as well as increase yield and nectar production. Thanks to this research work, we have several black locust cultivars and candidate cultivars available for use in industrial plantations (Keresztesi 1983, 1988; Rédei et al. 2001, 2002, 2008, 2017).

In the late 1990s, FRI researchers produced 15 micropropogated clones as part of a research programme to select clones that could be successfully grown on arid sites. Five of these (Robinia pseudoacacia 'Vacsi', Robinia pseudoacacia 'Szálas', Robinia pseudoacacia 'Oszlopos', Robinia pseudoacacia 'Homoki' and Robinia pseudoacacia 'Bácska') have been granted a provisionally approved cultivar candidate category by the Hungarian National Food Chain Safety Office (Rédei et al. 2002, 2006, 2008, 2013a, 2013b).

Apart from Hungary, several countries have initiated research programmes that aim to improve black locust wood quality and/or increase biomass production for energy purposes. Black locust breeding and improvement is undertaken in the USA (Bongarten et al. 1991, 
Straker et al. 2015), Germany (Liesebach et al. 2004, Böhm et al. 2011), Poland (SzypBorowska et al. 2016), Bulgaria (Kalmukov 2005, 2014), Greece (Dini-Papanastasi - Panetsos 2000), Turkey (Dengiz et al. 2010), India (Sharma et. al. 2006), China (Dunlun et al. 1995, Li et al. 2021), and South Korea (Lee et al. 2007). Countries are increasingly interested in black locust improvement and management, with special attention focused on the species' response to climate change impacts.

The main goals of this paper are as follows:

- providing a brief review of the international aspects of black locust propagation and improvement,

- documenting available knowledge about black locust candidate cultivars,

- presenting the most important results of growing black locust within the HungarianSouth Korean cooperation as a reference work.

\section{ORIGIN AND BOTANICAL DESCRIPTION OF THE BLACK LOCUST CANDIDATE CULTIVARS}

The black locust improvement (selection) programme launched in 1996 has two aims: to help quality development of black locust propagation material and to complete the variety choice of particular regions producing new black locust cultivars that can be grown effectively under unfavourably changed ecological conditions. The following are the main selection step processes: choice of black locust population containing trees of good phenotype; choice of plus trees; seed collection from the plus trees; seedling production, establishing a collection with the progenies of the plus trees; organizing a collection of seedlings selected from the progenies; clonal selection from the seedlings' collection by tissue culture (micropropagation) method; initiating clone trials for selecting the best clones. The programme has improved 15 new black locust clones (Rédei 2013). As mentioned above, five of these clones have recently been designated as candidate cultivars.

The following segment presents the botanical description of R. p. 'Homoki', R. p. 'Bácska', R. p. 'Vacsi' and R. p. 'Oszlopos' (R. p. 'Szálas' is not subject of this paper).

\subsection{Bácska (Robinia pseudoacacia 'Bácska')}

The breeding label for Bácska is $\mathrm{KH} 56 \mathrm{~A} \mathrm{2/5}$, which indicates the origin of the clone (KH means Kéleshalom). Bácska has medium density foliage, with 11-17 leaflets per leaf stalk. In most cases the leaflet is orderly elliptical possibly inversely egg-shaped, of which the tip is rounded or indented without any splinter. The length of spines ranges from 6 to $12 \mathrm{~mm}$. The base is small, possibly medium-sized, and evenly acuminate toward its point. The shoot is ribbed and uniformly salad-green. It develops many, relatively short shoots (not determining features, these depend mostly on the environment). The rod of 'Bácska' is strongly ribbed and spines, which subtend $90^{\circ}$ with the rod, cover its full length. These decrease evenly in size toward the apical part. Generally, 21 to 24 nodes are situated along the length of the $50 \mathrm{~cm}$ part of shoot. The bark is smooth and steel-grey in colour. The flower is white. The flowering-axis is green with medium-length. The flower cluster is loose; a cluster consists of 23-31 pieces of flowers. The calyx is green with brown pigmentation, but green-toned determinatively. After flowering, the colour changes to brownish-red. Bácska's flowering intensity was average at Kecskemét-Méheslapos in 2006 and in 2007. Its flowering began three days later than and lasted two days longer than the common black locust at Gödöllö (Osváth-Bujtás - Rédei 2007). 


\subsection{Homoki (Robinia pseudoacacia 'Homoki')}

The breeding label for this cultivar is $\mathrm{MB} 17 \mathrm{D} \frac{3}{4}$, which indicates the origin of the clone (MB means Mikebuda). 'Homoki' makes a dense foliage impression. The compound, which consists of 13-19 leaflets, is of an average length. Mid-positioned leaves are the largest ones. The leaflet is drawn; sometimes it is orderly elliptical-shaped of which the form factor is 3-3.5. The tip of the leaflet is mildly indented and lacks splinter. The spines are small, bodkin-like, and 5-8 mm in length. 'Homoki' black locust shoots are reddish, greenish-brown and are typically ribbed. Rods are strongly ribbed with a medium number of nodums (15-21). Tiny spines subtend at an acute angle (approx. $30^{\circ}$ ) with the rod. The bark is greyish-brown, with lenticels of scattered position emerging from the surface. Often longitudinal brown stripes can be seen on sapling bark. The flowering-axis is dull green with purple discoloration. The petals are white with mild greenish-yellow colour in the middle of the vexil. 'Homoki' began flowering at average time at Kecskemét-Méheslapos in 2006 but lasted 2-4 days longer than the common black locust at Gödöllő. Its flowering was abundant in 2006 and in 2007 (Osváth-Bujtás - Rédei 2007).

\subsection{Vacsi (Robinia pseudoacacia 'Vacsi')}

This clone is labelled as PV 201E2/1, which indicates the origin (PV means Pusztavacs). 'Vacsi' develops olive-green, relatively sparse foliage after leafing. On average, there are 1521 leaflets per leaf stalk. With the exception of the lowest leaflets, the mostly egg-shaped leaflets are identical in size. The form factor is 2.5-3. The leaf tips are rounded or indented and are ordered in an opposite leaf arrangement. Spines are mouse ear-like and small. Shoots are green, greenish-brown, and ribbed only on $5-15 \mathrm{~cm}$ of length on the youngest segments. The next part of shoot is cylindrical. The rod is covered by medium strong ribs, with an average number of nodums (19-21). Tiny spines are situated only on the lower part of the shoot. The bark of 'Vacsi' black locust is dark grey with scattered lenticels. It has white flowers and the flowering-axis is green. The calyx is light green and occasionally displays pink pigment; the petals are white with an olive-green spot. Flowering intensity was average at KecskemétMéheslapos in 2006 and was weak-medium in 2007 (Osváth-Bujtás - Rédei 2007).

\subsection{Oszlopos (Robinia pseudoacacia 'Oszlopos')}

The breeding label for this clone is PV 233A/1. It develops medium green rich foliage after vernal leafing. The compound leaf consists of 15-19 leaflets. The leaflet is elongated elliptical (its form factor is 3-3.5) with an acuminate tip, sometimes with splinter. The leaf base of leaflets is wedge-shaped. The 1-3 mm-long spines are situated on the underside of the rod. Their shape is uncharacteristic and nondescript. Shoots are light green, ribbed along 15-20 cm of length, while the other part of the shoot is cylindrical. Medium strong ribs, with many (27-30) nodums and little spines, cover the rods. Spines do not or hardly develop on the apical - longer - part of the rod and occur only along the lower $15-20 \mathrm{~cm}$. The bark is greenish-grey with scattered lenticels. Flowering intensity was average at Kecskemét-Méheslapos in 2006 and in 2007. The same applies to flower quantity (Osváth-Bujtás - Rédei 2007).

\subsection{Experiences of clone trials}

The Hungarian Forest Research Institute has three clone trials (Helvécia, Kecskemét and Hajdúhadház) where 'Bácska' and 'Homoki' candidate cultivars proved to be the best (Rédei et al. 2013a, 2013b). 


\section{MATERIALS AND METHODS}

\subsection{Site and stand parameters}

Data used in this study emanated from black locust clone trials established in the forest subcompartment Helvécia 22 E (two experimental plots) in Danube-Tisza Interfluve, "Homokhátság" (sandy ridge) region (Figure 1). In the past three decades, the mean annual precipitation at the site was $574 \mathrm{~mm}$ while the mean annual temperature was $11.4{ }^{\circ} \mathrm{C}$ (Tölgyesi et al. 2016). The FOA has recognized this region as an increasingly arid zone in its long-term forecast. The most pessimistic assessments predict the risk of desertification (UNCCD 2006).

The experimental plots are located in a forest-steppe climate. The soil is slightly humous, sandy, and free-draining (according to the Hungarian forest site classification by Járó, 1972). The black locust stands at the site ranged from 6 to 15 years.

In experimental plot 1, we compared 'Vacsi', 'Homoki' candidate cultivars and the common black locust (control). The examined trees were 15 years old at the time (January 2021) of the full inventory (Laar - Akca 2007).

In experimental plot 2, 'Jászkiséri' cultivar and 'Bácska' and 'Oszlopos' candidate cultivars were compared. These were 14-year-old trees.

In the experimental plots, 30 stems/clone were examined.

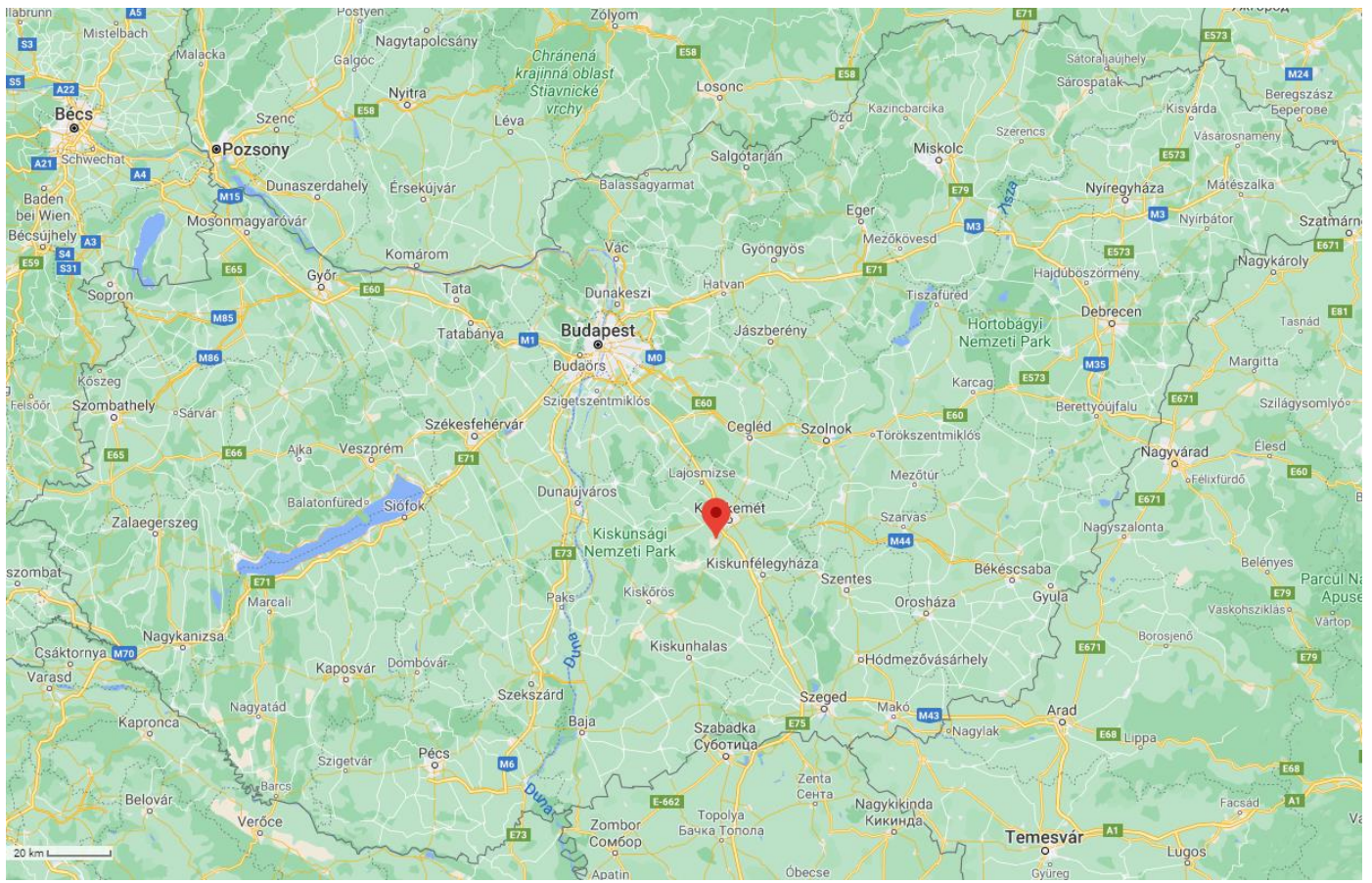

Figure 1. Location of the research site (Helvécia)

The location (forest subcompartment) and the most important dendrometric characteristics, including age, mean height $(\mathrm{H})$, mean diameter at breast height $(\mathrm{DBH})$, mean tree volume $(\mathrm{v})$ and stem form value (SFV), extended by data from previous full inventories (6-year-old and 7year-old trees) are compiled in Table 1. The stem volume was calculated using the following volume function based on the volume table for black locust (Sopp - Kolozs 2013):

$$
\mathrm{v}=10^{-8} \cdot \mathrm{d}^{2} \cdot \mathrm{h}^{1} \cdot(\mathrm{h} /[\mathrm{h}-1.3])^{2} \cdot(-0.6326 \cdot \mathrm{d} \cdot \mathrm{h}+20.23 \cdot \mathrm{d}+3034),
$$

where $\mathrm{v}$ is stem volume $\left(\mathrm{m}^{3}\right), \mathrm{d}$ is diameter at breast height $(\mathrm{cm}), \mathrm{h}$ is tree height $(\mathrm{m})$. The mean tree volume $\left(\mathrm{v}, \mathrm{m}^{3} /\right.$ tree $)$ was calculated using the means of stem volume for each of the 
experimental plots. The following classifications were used for the evaluation of stem form value (SFV): 1 - stem form is straight, 2 - more or less straight, 3 - crooked, 4 - very crooked.

Table 1. Parameters of black locust candidate cultivars, 'Jászkiséri' cultivar, and common black locust (control) at 6-15 years old

\begin{tabular}{lcccccc}
\hline Clones & $\begin{array}{c}\text { Experimental } \\
\text { plot }\end{array}$ & $\begin{array}{c}\text { Age } \\
(\mathrm{yr})\end{array}$ & $\begin{array}{c}\mathrm{H}_{\mathrm{m}} \\
(\mathrm{m})\end{array}$ & $\begin{array}{c}\mathrm{DBH} \\
(\mathrm{cm})\end{array}$ & $\begin{array}{c}\mathrm{v} \\
\left(\mathrm{m}^{3}\right)\end{array}$ & $\mathrm{SFV}$ \\
\hline Homoki & 1 & 7 & 8.7 & 6.2 & 0.0227 & 1.78 \\
Vacsi & 1 & 7 & 7.8 & 5.3 & 0.0147 & 1.36 \\
Common black locust & 1 & 7 & 6.36 & 3.86 & 0.0081 & 2.45 \\
Homoki & 1 & 15 & 10.5 & 9.8 & 0.0626 & 2.32 \\
Vacsi & 1 & 15 & 9.0 & 7.7 & 0.0327 & 1.66 \\
Common black locust & 1 & 15 & 9.77 & 7.56 & 0.0343 & 2.37 \\
\hline Bácska & 2 & 6 & 7.1 & 6.3 & 0.0131 & 1.74 \\
Oszlopos & 2 & 6 & 3.9 & 3.5 & 0.0034 & 2.23 \\
Jászkiséri & 2 & 6 & 6.28 & 5.81 & 0.0105 & 1.68 \\
Bácska & 2 & 14 & 11.4 & 11.2 & 0.0790 & 2.50 \\
Oszlopos & 2 & 14 & 6.7 & 7.6 & 0.0312 & 2.32 \\
Jászkiséri & 2 & 14 & 11.66 & 9.85 & 0.0616 & 1.96 \\
\hline
\end{tabular}

Note: PV 233 A/1 ('Oszlopos') candidate cultivars are situated on the poorest spot of the site

\subsection{Statistical analysis}

Microsoft Excel 2016 and IBM SPSS Statistics 25 software packages were used for the statistical analysis of experimental results. Candidate cultivars were compared using one-way ANOVA and Fisher's least significance difference (LSD) test $(p<0.05)$.

\section{RESULTS AND DISCUSSION}

Figure 2 presents the distribution of the candidate cultivars in the site index curves of the black locust yield table. As the figure shows, at 6 and 7 years old, the candidate cultivars (except 'Oszlopos' - PV 233A/1) belong to yield class I to III, and to yield class IV to VI at 14 and 15 years old.

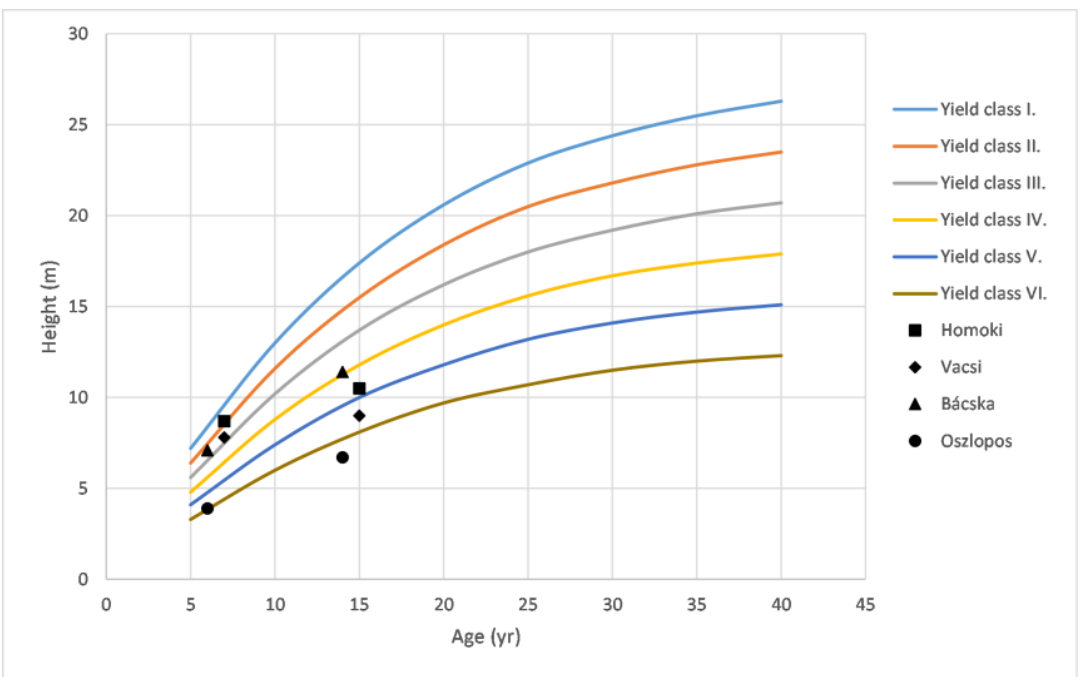

Figure 2. 6-15-year-old black locust candidate cultivars in the site index curves of black locust yield table (based on Rédei 1984) 
In this study, significant $(p<0.05)$ differences were observed between the examined candidate cultivars. More specifically, 15-year-old 'Homoki' outperformed the common black locust in diameter and mean tree volume; 'Vacsi' outperformed in stem quality (Table 2). The 14-year-old 'Bácska' cultivar candidate was compared with the 'Jászkiséri' cultivar and 'Oszlopos' cultivar candidate where 'Bácska' proved to be significantly better in diameter and mean tree volume, but weaker in stem quality than 'Jászkiséri' (Table 3).

Table 2. The result of one-way ANOVA (Helvécia 22 E/1)

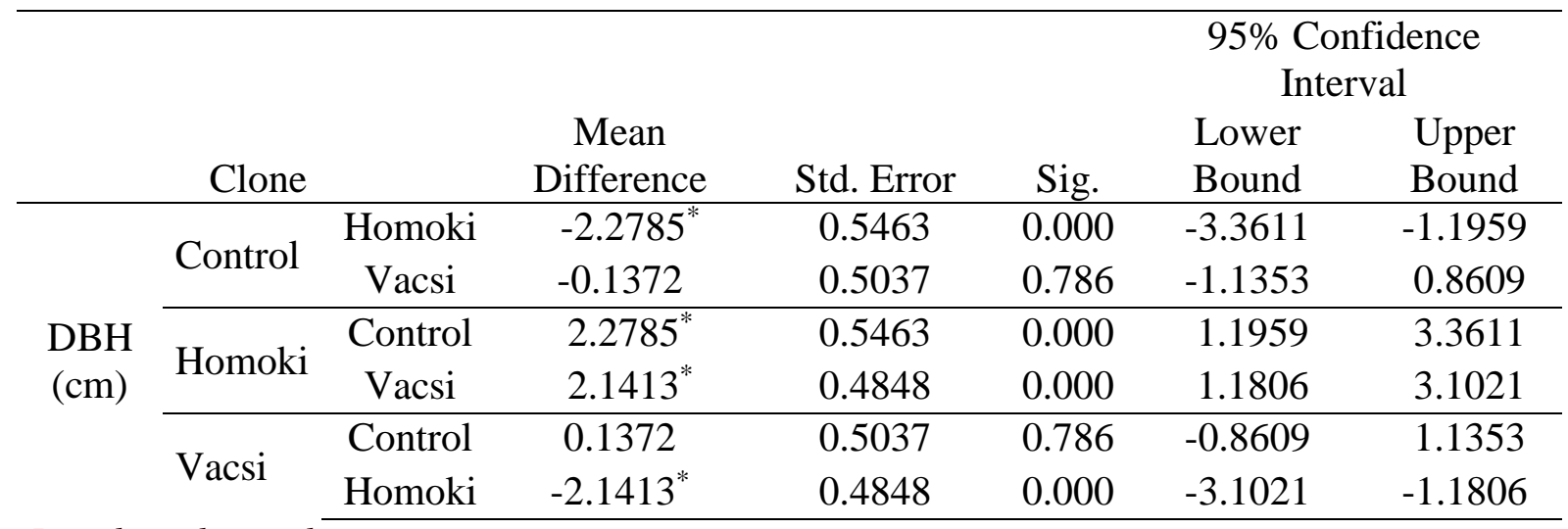

Based on observed means.

The error term is Mean Square (Error) $=4.757$

\begin{tabular}{|c|c|c|c|c|c|c|c|}
\hline \multirow{6}{*}{$\begin{array}{l}\text { Height } \\
\text { (m) }\end{array}$} & \multirow{2}{*}{ Control } & Homoki & -0.7480 & 0.4746 & 0.118 & -1.6886 & 0.1925 \\
\hline & & Vacsi & 0.7267 & 0.4376 & 0.100 & -0.1404 & 1.5938 \\
\hline & \multirow{2}{*}{ Homoki } & Control & 0.7480 & 0.4746 & 0.118 & -0.1925 & 1.6886 \\
\hline & & Vacsi & $1.4747^{*}$ & 0.4212 & 0.001 & 0.6401 & 2.3093 \\
\hline & \multirow{2}{*}{ Vacsi } & Control & -0.7267 & 0.4376 & 0.100 & -1.5938 & 0.1404 \\
\hline & & Homoki & $-1.4747^{*}$ & 0.4212 & 0.001 & -2.3093 & -0.6401 \\
\hline
\end{tabular}

Based on observed means.

The error term is Mean Square (Error) $=3.590$

\begin{tabular}{|c|c|c|c|c|c|c|c|}
\hline \multirow{6}{*}{$\begin{array}{c}\text { Mean } \\
\text { tree } \\
\text { volume } \\
\left(\mathrm{m}^{3}\right)\end{array}$} & \multirow{2}{*}{ Control } & Homoki & $-0.0282^{*}$ & 0.0066 & 0.000 & -0.0413 & -0.0151 \\
\hline & & Vacsi & 0.0017 & 0.0061 & 0.785 & -0.0104 & 0.0137 \\
\hline & \multirow[b]{2}{*}{ Homoki } & Control & $0.0282^{*}$ & 0.0066 & 0.000 & 0.0151 & 0.0413 \\
\hline & & Vacsi & $0.0299^{*}$ & 0.0059 & 0.000 & 0.0183 & 0.0415 \\
\hline & \multirow{2}{*}{ Vacsi } & Control & -0.0017 & 0.0061 & 0.785 & -0.0137 & 0.0104 \\
\hline & & Homoki & $-0.0299^{*}$ & 0.0059 & 0.000 & -0.0415 & -0.0183 \\
\hline
\end{tabular}

Based on observed means.

The error term is Mean Square (Error) $=0.001$

\begin{tabular}{cccccrrr}
\hline & \multirow{2}{*}{ Control } & Homoki & 0.0431 & 0.1419 & 0.762 & -0.2381 & 0.3243 \\
\cline { 3 - 7 } Stem & Vacsi & $0.7067^{*}$ & 0.1308 & 0.000 & 0.4474 & 0.9659 \\
\cline { 3 - 8 } form & \multirow{2}{*}{ Homoki } & Control & -0.0431 & 0.1419 & 0.762 & -0.3243 & 0.2381 \\
value & & Vacsi & $0.6635^{*}$ & 0.1259 & 0.000 & 0.4140 & 0.9131 \\
\cline { 2 - 7 } & \multirow{2}{*}{ Vacsi } & Control & $-0.7067^{*}$ & 0.1308 & 0.000 & -0.9659 & -0.4474 \\
& & Homoki & $-0.6635^{*}$ & 0.1259 & 0.000 & -0.9131 & -0.4140 \\
\cline { 2 - 7 }
\end{tabular}

Based on observed means.

The error term is Mean Square (Error) $=0.321$

*. The mean difference is significant at the 0.05 level 
Table 3. The result of one-way ANOVA (Helvécia 22 E/2)

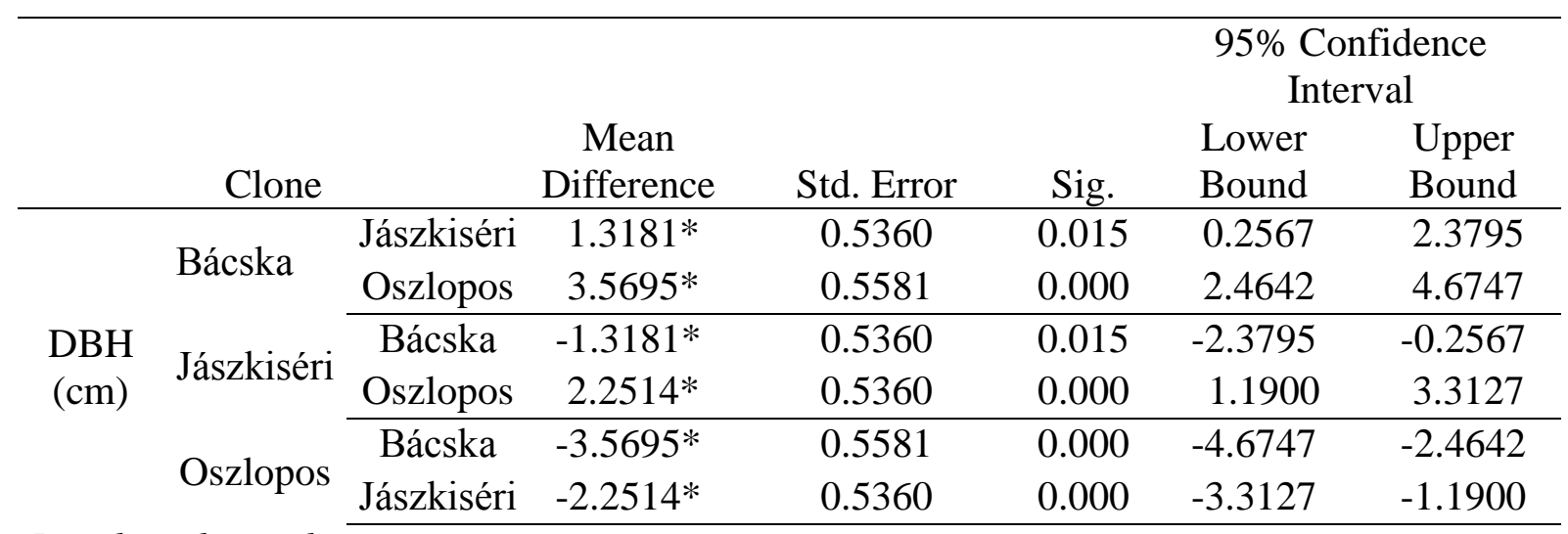

Based on observed means.

The error term is Mean Square(Error) $=5.919$

\begin{tabular}{|c|c|c|c|c|c|c|c|}
\hline \multirow{6}{*}{$\begin{array}{l}\text { Height } \\
\text { (m) }\end{array}$} & \multirow{2}{*}{ Bácska } & Jászkiséri & -0.2203 & 0.3351 & 0.512 & -0.8839 & 0.4433 \\
\hline & & Oszlopos & $4.7763 *$ & 0.3489 & 0.000 & 4.0853 & 5.4673 \\
\hline & \multirow{2}{*}{ Jászkiséri } & Bácska & 0.2203 & 0.3351 & 0.512 & -0.4433 & 0.8839 \\
\hline & & Oszlopos & $4.9966^{*}$ & 0.3351 & 0.000 & 4.3331 & 5.6602 \\
\hline & \multirow{2}{*}{ Oszlopos } & Bácska & $-4.7763^{*}$ & 0.3489 & 0.000 & -5.4673 & -4.0853 \\
\hline & & Jászkiséri & $-4.9966 *$ & 0.3351 & 0.000 & -5.6602 & -4.3331 \\
\hline
\end{tabular}

Based on observed means.

The error term is Mean Square (Error) $=2.313$

\begin{tabular}{cccccccc}
\hline \multirow{2}{*}{$\begin{array}{c}\text { Mean } \\
\text { tree }\end{array}$} & Bácska & Jászkiséri & $0.0174^{*}$ & 0.0073 & 0.018 & 0.0030 & 0.0317 \\
volume & Jászkiséri & Oszlopos & $0.0479^{*}$ & 0.0076 & 0.000 & 0.0329 & 0.0628 \\
\cline { 2 - 7 }$\left(\mathrm{m}^{3}\right)$ & Bácska & $-0.0174^{*}$ & 0.0073 & 0.018 & -0.0317 & -0.0030 \\
& Oszzlopos & Oszlopos & $0.0305^{*}$ & 0.0073 & 0.000 & 0.0161 & 0.0448 \\
\cline { 2 - 7 } & Bácska & $-0.0479^{*}$ & 0.0076 & 0.000 & -0.0628 & -0.0329 \\
& & Jászkiséri & $-0.0305^{*}$ & 0.0073 & 0.000 & -0.0448 & -0.0161 \\
\cline { 2 - 7 }
\end{tabular}

Based on observed means.

The error term is Mean Square(Error) $=0.001$

\begin{tabular}{|c|c|c|c|c|c|c|c|}
\hline \multirow{6}{*}{$\begin{array}{l}\text { Stem } \\
\text { form } \\
\text { value }\end{array}$} & \multirow{2}{*}{ Bácska } & Jászkiséri & $0.5444 *$ & 0.1210 & 0.000 & 0.3047 & 0.7842 \\
\hline & & Oszlopos & 0.1842 & 0.1260 & 0.147 & -0.0654 & 0.4338 \\
\hline & \multirow{2}{*}{ Jászkiséri } & Bácska & $-0.5444 *$ & 0.1210 & 0.000 & -0.7842 & -0.3047 \\
\hline & & Oszlopos & $-0.3602 *$ & 0.1210 & 0.004 & -0.5999 & -0.1205 \\
\hline & \multirow{2}{*}{ Oszlopos } & Bácska & -0.1842 & 0.1260 & 0.147 & -0.4338 & 0.0654 \\
\hline & & Jászkiséri & $0.3602 *$ & 0.1210 & 0.004 & 0.1205 & 0.5999 \\
\hline
\end{tabular}

Based on observed means.

The error term is Mean Square(Error) $=0.302$

*. The mean difference is significant at the 0.05 level

\section{CONCLUSIONS}

This study compared black locust candidate cultivars with common black locust and 'Jászkiséri' cultivars. After the evaluation of statistical analysis (one-way ANOVA) of experimental results, the present study found significant differences $(p<0.05)$ between the 
candidate cultivars and common black locust or 'Jászkiséri' locust. More specifically, 15-yearold 'Homoki' and 14-year-old 'Bácska' proved to be the best in diameter at breast height (9.8 $\mathrm{cm}$ and $11.2 \mathrm{~cm})$ and mean tree volume $\left(0.0626 \mathrm{~m}^{3}\right.$ and $\left.0.0790 \mathrm{~m}^{3}\right)$.

The evaluation of the experiment addresses the important fact of whether it is worthwhile to grow selected black locust cultivars and candidate cultivars on marginal sites. Detailed economic studies are needed to determine this, especially with regard to the expected added value (stem quality) of the candidate cultivars.

The Hungarian Forest Research Institute and the South Korean National Institute of Forest Science have been cooperating on the improvement of black locust cultivation in Hungary and South Korea for over ten years. The South Korean National Institute of Forest Science fully supports the project. Candidate cultivars evaluated in this manuscript are also available in South Korea and have been experimentally vegetative propagated and placed in variety comparison trials in recent years. The focus of our study was to investigate the growth relationships of the candidate cultivars on marginal sites, as the potential for future black locust propagation in such sites is under primary consideration in South Korea.

The systematic evaluation of the cultivation experiments and the selection of black locust clones and candidate cultivars to be proposed for public cultivation should be further extended to the following main fields:

- better definition of their site (ecological) requirements;

- development of a large-scale, profitable technology for their vegetative propagation (from root cuttings);

- further data collection and evaluation of the cultivation technological factors (planting spacing, mixing, cutting age, etc.) which are not yet sufficiently understood;

- extension of productivity (yield) studies, development of new yield models for groups of candidate cultivars;

- continued monitoring and evaluation of the resistance of candidate cultivars to biotic and abiotic pests;

- more consistent use of landscape ecology in species selection.

Acknowledgements: Prepared with the professional support of the Doctoral Student Scholarship Program of the Co-operative Doctoral Program of the Ministry of Innovation and Technology financed from the National Research, Development and Innovation Fund. Furthermore, the work is supported by the South Korean National Institute of Forest Science (NIFoS).

\section{REFERENCES}

Bongarten, B.C. - MerkLe, S.A. - Hanover, J.W. (1991): Genetically improved black locust for biomass production in short-rotation plantations. In: Energy from Biomass and Wastes XV (KLASS, D.L. ed.), Institute of Gas Technology, Chicago, IL. 391-409.

BÖHM, C. - QUINKENSTEIN, A. - FREESE, D. (2011): Yield prediction of young black locust (Robinia pseudoacacia L.) plantation for woody biomass production using allometric relations. Annals of Forest Research 54: 215-227.

DEMENÉ, J.M. - MERZEAU, D. (2007): Le robinier faux acacia, Historique et caractéristiques biologiques. Forêt-entreprise 177: 10-12. (in French)

Dengiz, O. - Gol, C. - SARIOGLU, F. E. - EdIS, S. (2010): Parametric approach to land evaluation for forest plantation: A methodological study using GIS model. African Journal of Agricultural Research 5 (12): 1482-1496. 
DINI-PAPANASTASI, O. - PANETSOS, C.P. (2000): Relation between growth and morphological traits and genetic parameters of Robinia pseudoacacia var. monophylla DC in northern Greece. Silvae Genet. 49: 37-44.

DUNLUN, Z. - ZHENFEN, Z. - FANGQUAN, W. (1995): Progress in clonal selection and breeding of black locust (Robinia pseudoacacia L.) In: Forest Tree Improvement in the Asia-Pacific Region (Xihuan Shen): China Forestry Publishing House, Beijing, 152-156.

HungaRian CENTRAL STATISTICAL OfFiCE (HCSO) (2019): A faállománnyal borított erdőterület és az élőfakészlet megoszlása fafajcsoportok és korosztályok szerint (2010-2019) online: https://www.ksh.hu/docs/hun/xstadat/xstadat eves/i ome002b.html (in Hungarian)

JÁRÓ, Z. (1972): A termőhely fogalma. In: Danszky I. (ed.): Erdőművelés I. Mezőgazdasági Kiadó, Budapest, 47-87. (in Hungarian)

KALMUKOV, K. (2005): Growth and yield of pure and mixed black locust cultures. In: Proceedings of the symposium forest and sustainable development. Transylvania University of Brașov, Brașov, pp 91-96.

KALMUKOV, K. (2014): Improvement of black locust stands in Bulgaria. Gora 6-7: 24-26 (in Bulgarian)

KERESZTESI, B. (1983): Breeding and cultivation of black locust (Robinia pseudoacacia L.) in Hungary. Forest Ecology and Management 6: 217-244.

KereszTeSI, B. (Ed.) (1988): The Black Locust. Akadémiai Kiadó, Budapest.

LAAR, A. - AKÇA, A. (2007): Forest Mensuration. City, Springer: 377.

LEE, C.S. - CHO, H.J. - YI, H. (2004): Stand dynamics of introduced black locust (Robinia pseudoacacia L.) plantation under different disturbance regimes in Korea. Forest Ecology and Management 189: 281-293. https://doi.org/10.1016/j.foreco.2003.08.012

LEE, H. - LiM, H. - KANG, J.-W. (2019): Growth Performance of Exotic Trees in Korea. Journal of Forest and Environmental Science 35 (2): 115-120. https://doi.org/10.7747/JFES.2019.35.2.115

LEE, K.J. - SOHN, J.H. - RÉDEI, K. - YUN, H.Y. (2007): Selection of early and late flowering Robinia pseudoacacia from domes-ticated and introduced cultivars in Korea and prediction of flowering period by accumulated temperature. Journal of Korean Forest Society 96: 170-177.

LI, G. - XU, G. - GUO, K. - DU, S. (2014): Mapping the global potential geographical distribution of black locust (Robinia Pseudoacacia L.) using herbarium data and a maximum entropy model. Forests 5: 2773-2792. https://doi.org/10.3390/f5112773

LI, X. - Zhang, Z. - ReN, Y. - FenG, Y. - GuO, Q. - DONG, L. - Sun, Y. - LI, Y. (2021): Induction and early identification of tetraploid black locust by hypocotyl in vitro. In Vitro Cellular and Developmental Biology - Plant 57: 372-379. https://doi.org/10.1007/s11627-020-10133-5

LIESEBACH, H. - YANG, M. S. - SCHNECK, V. (2004): Genetic diversity and differentiation in a black locust (Robinia pseudoacacia L.) progeny test. Forest Genetics 11 (2): 151-161.

NICOLESCU, V.N. - RÉDEI, K.-MASON, W.L. ET AL. (2020): Ecology, growth and management of black locust (Robinia pseudoacacia L.), a non-native species integrated into European forests. Journal of Forestry Research 31: 1081-1101. https://doi.org/10.1007/s11676-020-01116-8

NOH, N.J. - SON, Y. - KoO, J.W. - SEO, K.W. - KIM, R.H. - LEE, Y.Y. - YOO, K.S. (2010): Comparison of nitrogen fixation for north- and south-facing Robinia pseudoacacia stands in central Korea. Journal of Plant Biology 53: 61-69. https://doi.org/10.1007/s12374-009-9088-9

OsvÁtH-BuJTÁs, Z. - RÉDEI, K. (2007): Akác fajtaismertető. Agroinform Kiadó. Budapest. 36. (in Hungarian)

RÉDEI, K. - OSTVÁTH-BujtÁs, Z. - BALLA, I. (2001): Propagation methods for black locust (Robinia pseudoacacia L.) improvement in Hungary. Journal of Forestry Research 12 (4): 215-219. https://doi.org/10.1007/BF02856710

RÉDEI, K. - OSTVÁTH-BUJTÁs, Z. - BALLA, I. (2002): Clonal approaches to growing black locust (Robinia pseudoacacia L.) in Hungary: a review. Forestry 75 (5): 548-552. https://doi.org/10.1093/forestry/75.5.547

RÉDEI, K. - OSVÁTH-BUJTÁs, Z. - VEPERDI, I. (2006): Black locust (Robinia pseudoacacia L.) clonal seed orchards in Hungary. Silva Balcanica 7 (1): 63-68.

RÉDEI, K. - OSVÁTH-BUJTÁS, Z. - VEPERDI, I. (2008): Black locust (Robinia pseudoacacia L.) improvement in Hungary: a review. Acta Silvatica et Lignaria Hungarica 4:127-132.

RÉDEI, K. (1984): Akácosok fatermése. ERTI Kutatási jelentés. Kecskemét (in Hungarian) 
RÉDEI, K. (Ed.) (2013): Black locust (Robinia pseudoacacia L.) Growing in Hungary. Agroinform Kiadó, Budapest.

RÉDEI, K. - KESERÜ, Z. - RÁSÓ, J. (2013a): Early evaluation of micropropagated black locust (Robinia pseudoacacia L.) clones in Hungary. Forest Science and Practice 15: 81-84.

RÉDEI, K. - KESERÜ, ZS. - CSIHA, I. - RÁSÓ, J. - KAMANDINÉ VÉGH, Á. - ANTAL, B. (2013b): Juvenile growth and morphological traits of micropropagated black locust (Robinia pseudoacacia $\mathrm{L}$.) clones under arid site conditions. Acta Silvatica et Lignaria Hungarica 9: 35-42.

RÉDEI, K. - CSIHA, I. - RÁSÓ, J. - KESERÜ, ZS. (2017): Selection of promising black locust (Robinia pseudoacacia L.) cultuvars in Hungary. Journal of Forest Science 63 (8): 339-343. https://doi.org/10.17221/23/2017-JFS

SHARMA, K.R. - PUNEET, S. (2006): Variation in wood character-istics of Robinia pseudoacacia Linn. managed under high density short rotation system. In: Verma K.S., Khurana D.K., Christersson L. (eds): Proceedings of IUFRO In-ternational Conference on World Perspective on Short Rotation Forestry for Industrial and Rural Development, Nauni-Solan, Sept 7-13, 2003: 233-237.

SCHNECK, V. (2010): Robinie - Züchtungsansätze und Begründungsverfahren. In: Deutschland / Bundesministerium für Ernährung, Landwirtschaft und Verbraucherschutz (eds) Beiträge Agrarholz 2010: Symposium am 18. und 19. Mai 2010 in Berlin. Bonn: BMELF, pp 1-8, online:

http://veranstaltungen.fnr.de/fileadmin/allgemein/pdf/veranstaltungen/Agrarholz2010/11_2_Beitr ag_Schneck.pdf. Accessed 15th April 2021 (in German)

SopP L. - KolOZS L. (2013): Fatömegszámítási táblázatok. 4th Ed. Budapest, National Food Chain Safety Office, State Forest Service: 280 (in Hungarian)

STRAKER, K.C. - QUinN, L.D. - VoigT, T.B. - LEE, D.K. - KLING, G.J. (2015): Black Locust as a bioenergy feedstock: A review. Bioenergy Research 8: 1117-1135. https://doi.org/10.1007/s12155-015-9597-y

TÖlgYesi, Cs. - ZAlatNAi, M. - ERDÖS, L. - BÁtORI, Z. - HuPP, N.R. - KÖRMÖCZI, L. (2016): Unexpected ecotone dynamics of a sand dune vegetation complex following water table decline. Journal of Plant Ecology 9 (1): 40-50. https://doi.org/10.1093/jpe/rtv032

UNCCD (2006): Second National Report of the Republic of Hungary on the implementation of the United Nation Convention to Combat Desertification. Budapest: Ministry of Environment and Water of the Republic of Hungary.VADAS, J. (1911): Az ákácfa monográfiája. Budapest. 236. (in Hungarian)

VÍtKOVÁ, M. - TONIKA, J. - MÜLLEROVÁ, J. (2015): Black locust - successful invader of a wide range of soil conditions. Science of the Total Environment 505: 315-328. https://doi.org/10.1016/j.scitotenv.2014.09.104

VítKovÁ, M. - MÜllerová, J. - SÁDlo, J. - Pergl, J. - PYŠEK, P. (2017): Black locust (Robinia pseudoacacia) beloved and despised: A story of an invasive tree in Central Europe. Forest Ecology and Management 384: 287-302. https://doi.org/10.1016/j.foreco.2016.10.057 
